\title{
The Bank Robbery
}

\section{Sam Wilkinson}

Wham!

The door flew open upon impact from a large, black boot. As it swung off its hinges three men stepped through, armed and dangerous. Black balaclavas covered their faces, guns pointing menacingly at the onlookers as all three of them stood with their legs apart and their faces cold and unflinching in a well-rehearsed attempt to portray the very essence of badassery. Their slight Vformation had a rather boy-band vibe, but that was dispelled by the shotguns, pistols, and large, empty sacks. One of them even had a pair of aviator sunglasses on over his balaclava. He aimed onehanded and blew a surveillance camera off the ceiling with the stone cold grace and finesse of one who has watched too many gangster movies. Pure badass. 
A shotgun-blast into the air grabbed the attention of all in the bank, and was followed by an applause of shrieks and panicked ducking. Moving across the floor, like sharks through a swimming pool, they approached the counter, shooting looks of solid badass into any bystanders who dared pull their heads from between their legs. The middle one presented a large bag to the bank teller, a Clint Eastwood-style revolver adding incentive for the teller to fill it.

He demonstrated his fluency in bank robber dialects. 'And don't try any funny business. If the cops show up the first thing I'ma do is blow yer fuckin' brains out.' His two cronies were watching his back, doing a first-rate job of acting threatening.

The bank teller was a skinny, middle-aged man with the kind of thick glasses appropriate for a disheveled, nervous, scrawny geek. He looked as if he would tremble like a second-hand washing machine when talking to telemarketers from Delhi, let alone bank robbers oozing badass and bullets. His scruffy shirt was stuffed into the front of his grey plaid pants, which were held up with a pair of black suspenders. He looked as though he might fill them with excrement at any moment. The bank teller's hands shot upwards of their own accord in the universal position of 'please don't hurt me, I'm too pathetic to die.' He was apparently too busy repressing a girlish scream to have any conscious control of his own body movements.

'Take it!' He shrieked on the edge of tears. 'Take it all! Just don't hurt me!'

The bank robbers laughed a deep, masculine laugh as they leapt over the counter to make sure no funny business could be tried. One of them shot the change weighing machine on the way over, and gave a wicked snigger. 
'This all there is?' The talking bank robber inquired, his cowboy revolver demanding an answer.

'Well...' the bank teller shook and struggled for words. Not known for his steely resolve, his nervous system was more likely made up of talcum powder.

'Tell us, faggot!' Sunglasses Bank Robber desperately wanted to show off that he could talk too. That he grabbed the bank teller with both hands was completely unnecessary; there were already enough guns being pointed around to coerce the bank teller into revealing whatever information the bank robbers wanted.

'Bah-tha-I-there's a s-s-safe 'round the b-back.' The bank teller could scarcely speak through his terror, 'I have the k-k-key right h-here.'

In return for his compliance the bank teller found the barrel of Clint Eastwood's favourite pushed into his neck so hard it left a little red mark.

'Take us to it!'

Like a mutinous pirate walking the plank, the bank teller was pushed down the corridor with a shotgun in his back. He trembled along the corridor, and each time the bank robbers felt compelled to let a shot off into the ceiling, he shook like an epileptic raver and let out a high-pitched yelp. Eventually he came to a big, importantlooking door, made of reinforced steel with lots of bolts and rivets and bars stuck to it for no other reason than to make it look more intimidating. It seemed driven to out-badass the bank rovers lumbering towards it.

'Open it!' 
The bank teller dragged his quivering body towards the lock, inserted his key and turned it. The cold steel swung open, and the ominous darkness from within the vault seemed to pour into the corridor. It held open its arms, inviting the bank robbers in with the promise of wealth and glory, and they couldn't resist its hedonistic siren song. They ran towards the opening door, bags open and guns at their sides. As they dove thirstily into the blackness the bank teller closed the door behind them and locked it, making sure that it made a big, deep, metallic sound which served no purpose other than to let the bank robbers know that they had been out badassed. For as soon as the lights inside the vault turned on, they saw not gold or money waiting for them, but the skeletons of their predecessors. All of the previous bank robbers who had been led into the vault by a devious and deceptive bank teller sat there still, rotted to the bone, clutching their guns and their bags of money. 